\title{
The Impact of Experimental Temperature and Water Level Manipulation on Carbon Dioxide Release in a Poor Fen in Northern Poland
}

\author{
Mateusz Samson ${ }^{1}$ (D) Sandra Słowińska ${ }^{2,3} \cdot$ Michał Słowiński $^{4} \cdot$ Mariusz Lamentowicz $^{5,6} \cdot$ Jan Barabach $^{5}$. \\ Kamila Harenda ${ }^{1}$ • Małgorzata Zielińska ${ }^{5}$. Bjorn J. M. Robroek ${ }^{7,8,9}$ • Vincent E. J. Jassey ${ }^{7}$. Alexandre Buttler ${ }^{5,7,9,10}$. \\ Bogdan H. Chojnicki ${ }^{1}$
}

Received: 6 March 2017 / Accepted: 10 January 2018 / Published online: 23 January 2018

(C) The Author(s) 2018. This article is an open access publication

\begin{abstract}
Peatlands are ecosystems for which carbon budget relies strongly on the meteorological and hydrological conditions. Here, using a manipulative field experiment, we measured ecosystem respiration $\left(\mathrm{R}_{\mathrm{ECO}}\right)$ over two years (2013-2014) in a poor fen in Poland to estimate the carbon emission in a changing climate. The experiment consisted of warming (open-top chambers - OTC) and water table manipulation. The application of OTC increased the mean values of daily maximum air temperature by approx. 1.1$1.8{ }^{\circ} \mathrm{C}$. Warming or the increased water table depth separately resulted in an increase in ecosystem respiration by approx. $0.1 \mu \mathrm{mol} \mathrm{CO} \mathrm{Cm}^{-2} \mathrm{~s}^{-1}$ and $0.3 \mu \mathrm{mol} \mathrm{CO} \mathrm{m}^{-2} \mathrm{~s}^{-1}$, respectively. However, our results show also the additive nature of warming and water table drawdown impact on daily $\mathrm{R}_{\mathrm{ECO}}$ during the studied years $\left(2013-0.80 \mu \mathrm{mol} \mathrm{CO} \mathrm{m}^{-2} \mathrm{~s}^{-1}\right.$ and 2014-1.16 $\mu \mathrm{mol}$ $\mathrm{CO}_{2} \mathrm{~m}^{-2} \mathrm{~s}^{-1}$ ). With the natural dry period event which occurred in 2014, the seasonal $\mathrm{R}_{\mathrm{ECO}}$ increased by approx. $0.2 \mu \mathrm{mol} \mathrm{CO}_{2}$ $\mathrm{m}^{-2} \mathrm{~s}^{-1}$ as compared to the previous year. Projected global warming will therefore significantly enhance $\mathrm{C}$ loss from poor fens in this region of Europe.
\end{abstract}

Keywords Poor fen $\cdot$ Climate change $\cdot$ Ecosystem respiration $\cdot$ Open top chambers · Water table depth $\cdot$ Climate manipulation design

Mateusz Samson

samson.mateusz@gmail.com

1 Meteorology Department, Poznan University of Life Sciences, ul. Piątkowska 94, 60-649 Poznań, Poland

2 Institute of Geography and Spatial Organization, Department of Geoecology and Climatology, Polish Academy of Sciences, Twarda 51/55, 00-818 Warszawa, Poland

3 Department of Water Engineering and Management, Institute of Technology and Life Sciences, Falenty, al. Hrabska 3, 05-090 Raszyn, Poland

4 Department of Environmental Resources and Geohazard, Institute of Geography, Polish Academy of Sciences, Kopernika 19, 87-100 Torun, Poland

5 Department of Biogeography and Palaeoecology, Faculty of Geographical and Geological Sciences, Adam Mickiewicz University, ul. Dzięgielowa 27, 61680 Poznań, Poland
6 Laboratory of Wetland Ecology and Monitoring, Faculty of Geographical and Geological Sciences, Adam Mickiewicz University, Dzięgielowa 27, PL-61 680 Poznań, Poland

7 School of Architecture, Civil and Environmental Engineering ENAC, Laboratory of Ecological Systems ECOS, Ecole Polytechnique Fédérale de Lausanne EPFL, Station 2, 1015 Lausanne, Switzerland

8 Biological Sciences, University of Southampton, Southampton SO17 1BJ, UK

9 Snow and Landscape Research WSL, Swiss Federal Institute for Forest, Site Lausanne, Station 2, 1015 Lausanne, Switzerland

10 Laboratoire de Chrono-Environnement, UMR CNRS 6249, UFR des Sciences et Techniques, 16 route de Gray, Université de Franche-Comté, F-25030 Besançon, France 


\section{Introduction}

Peatlands play an important role in the global carbon cycle, despite the fact that they cover less than $3 \%$ of the global land area. With an estimated 270-547 Pg carbon (C) stored as peat (Clymo et al. 1998; Turunen et al. 2002; Yu et al. 2010) - i.e. $50-500 \mathrm{~kg} \mathrm{C} \mathrm{m}^{-2}$ - peatland ecosystems comprise over one-third of the global soil carbon pool (Gorham 1991; Lappalainen 1996; Rydin and Jeglum 2013). Peatlands are largely located in the northern hemisphere, almost $80 \%$ can be found in the boreal and subarctic zones (Smith et al. 2007; Yu et al. 2010), 10\% in the tropics and Southeast Asia, and $10 \%$ in the temperate zone (Lappalainen 1996; Frolking et al. 2011).

Peatlands have for long been considered as economically useful sources of carbon (Kirkinen et al. 2007, 2010), but recently the attention shifted towards their conservation due to their role in the global carbon cycle, affecting global climate (Frolking et al. 2011). Their functioning as carbon sink, however, relies both on temperature and hydrology (Fekete et al. 2010), which in turn affects the groundwater table, and indeed these are the main drivers controlling $\mathrm{C}$ fluxes in peatland ecosystems (Gunnarsson 2005; Limpens et al. 2008; Lund et al. 2010; Waddington et al. 2015). However, various disturbances affect the $\mathrm{C}$ sink potential, most often implying changes in soil microbial activities (Strack and Waddington 2007; Dorrepaal et al. 2009; Dieleman et al. 2015; Robroek et al. 2015; Pullens et al. 2016) or plant community composition (Dorrepaal et al. 2003; Buttler et al. 2015).

Increase global warming is an important driver of change in the carbon balance of these ecosystems (Alm et al. 1999). Over the period of 1906-2005, global air temperatures increased by about $0.7{ }^{\circ} \mathrm{C}$ (IPCC Working Group 1 et al. 2013). Notably, the last decade of that period was the warmest on record (IPCC Working Group 1 et al. 2013). Further, general climate models predict temperature to increase by additional $2-8{ }^{\circ} \mathrm{C}$, depending on the region, by the end of the twenty-first century (Christensen et al. 2007). As reported by NASA and NOAA, 2016 was the warmest year on record globally (Northon 2017). Additionally, IPCC predicts patterns in precipitation to change, with more intensive (extreme) rainfall periods that alternate periods of drought (IPCC Working Group 1 et al. 2013). Together, these changes in climate conditions will alter the hydrological conditions in peatlands and will modify processes related to the carbon cycle. Understanding the importance of biotic and abiotic controls on carbon fluxes from peatlands is, therefore, crucial to infer the role of climate change on the feedback of carbon to the atmosphere (Turetsky et al. 2002; Limpens et al. 2008). Additionally, water table drawdown, and long periods without rain, can thus significantly impact the structure of the microbial community
(Jaatinen et al. 2007) and the functioning of peatlands (Weltzin et al. 2003; Bragazza 2008), which then can (temporarily) shift from $\mathrm{C}$ sinks to $\mathrm{C}$ sources (Lafleur et al. 2005; Lund et al. 2012).

The potential of northern peatlands to accumulate carbon (C) is largely determined by the balance between carbon uptake by its vegetation (i.e. through photosynthesis) and carbon release from the peat soil (Alm et al. 1997). Increase global warming, such as the increased temperature and resulting water table drawdown, may imbalance peatland carbon cycles, resulting in a large feedback to the global climate. Results from a recent gradient study have identified reduced peat moss production and increased ecosystem respiration as the main cause of the reduced $\mathrm{C}$ uptake by alpine peatlands subjected to the increased temperature and long periods without rain (Bragazza et al. 2016). The authors noted that the increased uptake by the vascular plant community could not compensate for the negative effects of the ecosystem respiration.

Ecosystem respiration $\left(\mathrm{R}_{\mathrm{ECO}}\right)$ is usually defined as the sum of autotrophic and heterotrophic respiration (Giardina and Ryan 2000; Valentini et al. 2000). Dorrepaal et al. (2009) have shown that in peat soils, $70 \%$ of $R_{E C O}$ is accounted by heterotrophic respiration (i.e. decomposition). Therefore, $\mathrm{R}_{\mathrm{ECO}}$ seems mainly driven by abiotic conditions, such as soil moisture and temperature (Komulainen et al. 1999; Dorrepaal et al. 2009). However, the relative importance of temperature and hydrological conditions for $\mathrm{R}_{\mathrm{ECO}}$ is unclear and seems to depend on their relative effect on autotrophic and heterotrophic pathways, which might be decoupled (Lafleur et al. 2005). Remarkably, the effect of vegetation on heterotrophic respiration seems to be larger than the effect of temperature (Ward et al. 2015) or water table (Turetsky et al. 2008), highlighting the importance of these biotic controls on peatland carbon fluxes.

Using an innovative approach of water table manipulation, combined with the use of open-top chambers (OTC's) to increase air and peat temperature, we studied the effect of the water table drawdown and increased temperature on the $\mathrm{R}_{\mathrm{ECO}}$. By experimentally raising or elevating $1 \times 1 \mathrm{~m}$ 'intact soil monoliths' within their surrounding soil, thus maintaining a hydrological connection with the surrounding peat matrix, we were able to manipulate the water table, without any concomitant change in the plant and microbial community (as generally seen in microtopographical gradient studies) (Lamentowicz et al. 2016). We hypothesized that the increased temperature and decreased water table level would result in the increased loss of carbon by respiration, and that the effects of both are additive. Furthermore, we hypothesized that seasonality in respiration rates should follow the patterns in monthly temperature, yet that these relationships are expected to be higher in dry conditions as compared to wet conditions. 


\section{Materials and Methods}

\section{Study Site}

The experimental site, Linje mire $\left(53^{\circ} 11^{\prime} 15^{\prime \prime} \mathrm{N}, 18^{\circ} 18^{\prime} 34^{\prime \prime} \mathrm{E}\right)$, is located in northern Poland (Fig. 1), at $91 \mathrm{~m}$ a.s.l. The site (approx. $6 \mathrm{ha}$ ) is classified as a poor fen with ombrotrophic vegetation in the central part (Kucharski and Kloss 2005). It was drained in the past (dysfunctional drainage ditches are still visible on the peatland surface - Boński and Bońska 2004), but it has been under protection since 1901. The climate is mild oceanic to mild continental (Kottek et al. 2006); mean annual air temperature is approx. $8.0-8.5^{\circ} \mathrm{C}$, and annual precipitation varies between 500 and $550 \mathrm{~mm}$ (1971-2000) (Lorenc 2005; Hałas et al. 2008).

The dominant plants species in the experimental area is Sphagnum fallax (H. Klinggr.). The vascular plant community is dominated by the tussock cottongrass (Eriophorum vaginatum L.) and the common sedge (Carex rostrata Stokes), which are accompanied by the common cranberry (Oxycoccus palustris L.), the pine (Pinus sylvestris L.) and the marsh tea (Rhododendron tomentosum Stokes). Endemic to the site, and a glacial relict, is the dwarf birch (Betula nana L.) (Kloss 2005; Kloss and Żurek 2005).

Within the experimental area, we selected $281 \times 1 \mathrm{~m}$ plots with homogeneous plant species assemblage and comparable water table depths. A boardwalk was constructed to prevent damages caused by trampling during the measurements and maintenance works. Half of the plots were covered with opentop chambers (OTCs) that served to increase air temperature. The remaining half of the plots served as ambient controls
(CTL). Within both treatments (OTC and CTL), in three plots water table depth was increased $($ dry $-\mathrm{D})$, whilst in the other three plots water table depth was decreased (wet - W). Further, three plots were assigned as control treatments, and as such water table remained non-manipulated. For simplicity, these plots are hereafter referred to as 'cut' water table plots (cut $-\mathrm{C}$ ). The wet plots were constructed by cutting and removing three $50 \times 50 \times 30(1 \times \mathrm{w} \times \mathrm{h})$ blocks of peat including vegetation. We then removed $10 \mathrm{~cm}$ of the underlying peat, after which the earlier removed blocks were carefully replaced. This resulted in water table depths under the peat surface in the plots to be decreased by $10 \mathrm{~cm}$, without losing the hydrological connection with the surrounding peat matrix. This whole procedure was repeated for the dry plots, but in this case the $10 \mathrm{~cm}$ of peat that earlier was removed from the wet plots was added to the plots before replacing the peat block plus vegetation. This procedure resulted in plots where the water table was manipulated without changing the hydrological context, but with the increased water table depths of $10 \mathrm{~cm}$. The plots with non-manipulated water table received exactly the same treatment, but no peat was removed or added before placing back the peat blocks plus vegetation. The whole procedure led to triplicated plots with all combinations of increased temperature (OTC) or ambient temperature (CTL), and reduced water table depth (wet - W), ambient water depth (cut - C), and increased water table depth (dry D) (Fig. 1). All 18 experimental plots were bordered with plastic sheeting (15 cm height) so as to maintain the structure of the moss carpet. To control the effect of cutting, the remaining 10 plots - which had intact (uncut) peat soil - only received either the OTC (OTC, $n=5$ ) or remained non-covered
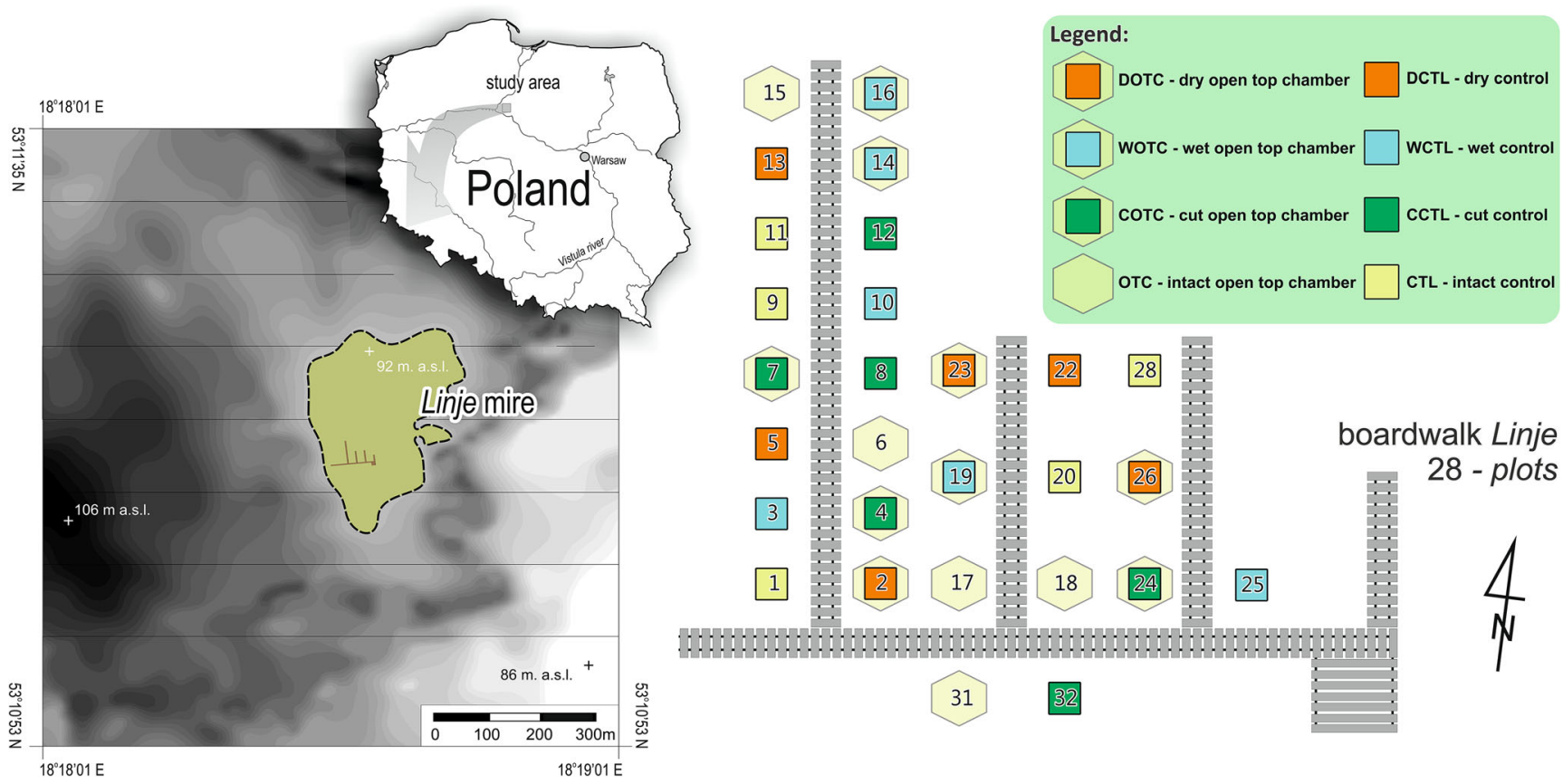

Fig. 1 Linje mire location and experimental design 
(CTL) (Lamentowicz et al. 2016). OTCs were constructed according to the ITEX protocol (Shaver et al. 2000), and consisted of transparent polycarbonate hexagonal chambers (50 cm high, $1.7 \mathrm{~m}$ top-width, $2.4 \mathrm{~m}$ base-width). OTCs allow quasi-natural transmittance of visible wavelengths, and minimize the transmittance of re-radiated infrared wavelengths (Marion et al. 1997). All OTCs were raised $10 \mathrm{~cm}$ above the peat surface to allow air circulation (Lamentowicz et al. 2016).

\section{Measurements of Meteorological Variables}

Soil temperature sensors (5TM; Decagon Devices, USA) were installed in all plots at $5 \mathrm{~cm}$ depth below the peat moss surface. These sensors registered the peat temperature (Ts) at $5 \mathrm{~s}$ intervals, after which 2-min average values were logged (CR1000, Campbell Sci., U.S.A.). These data were used to calculate mean daily soil temperature. Simultaneously, air temperature (Ta) was recorded using HOBO U23 Pro v2 data loggers (Onset Computer Corporation, USA). The sensors were installed at the height of $30 \mathrm{~cm}$ above the soil surface to monitor the microclimate in each plot. These parameters were measured every $10 \mathrm{~min}$ and used to calculate mean daily Ta.

To record water table depths (WTD), HOBO U20-001-01 pressure data loggers (Onset Computer Corporation, USA) were installed in four wells $(5 \mathrm{~cm}$ diameter and $2 \mathrm{~m}$ long PVC wells) around the experimental site. These loggers were set to record pressure every $3 \mathrm{~h}$ and data were averaged to calculate daily values. WTD within each plot was then calculated using experimental treatment $(-10 \mathrm{~cm}, 0 \mathrm{~cm}$ and $+10 \mathrm{~cm})$ relative to the averaged water table depth across the experimental site. These calculated values were calibrated by manual measurements conducted from time to time in the pipe placed in the center of each plot for hydrochemistry measurements.

Precipitation was recorded continuously $1 \mathrm{~m}$ above the soil surface using a tipping bucket Rain Gauge Smart Sensor (SRGB-M002) with a resolution of $0.2 \mathrm{~mm}$. This sensor was connected to HOBO U30 USB Weather Station Data Logger (Onset Computer Corporation, USA) and the interval of measurements was $10 \mathrm{~min}$.

\section{Measurements of $\mathrm{CO}_{2}$ Exchange}

At each plot, $\mathrm{CO}_{2}$ efflux was measured using a dynamic closed chamber system (darkened net canopy assimilation chamber; PP-Systems CPY-4) and an infrared gas analyzer (PP-Systems EGM-4) in a Sphagnum dominated surface where the collar of $20 \mathrm{~cm}$ diameter was inserted into the soil to $10-\mathrm{cm}$ depth. During the experiment, the collars were kept free of vascular plants. The $\mathrm{CO}_{2}$ concentration was recorded at 4-s intervals for $2 \mathrm{~min}$. The measurement campaigns were carried out every two weeks during the growing season (April-November). At each campaign field, measurements were performed repeatedly during a full day, using three analyzers and a stochastic sampling scheme for the path of plot measurements. Fluxes are expressed in $\mu$ mol $\mathrm{CO}_{2}$ $\mathrm{m}^{-2} \mathrm{~s}^{-1}$.

\section{Data Analysis}

Initially, basic statistical characteristics (mean, minimum, maximum) have been calculated for each variable collected in each plot for different time intervals $(30 \mathrm{~min}$, day, month and year) in order to check the data on quality prior to further statistical use. The collected data were categorized according to the manipulative treatments in order to analyze their effect on micrometeorological variables such as daily mean Ts, daily mean Ta, daily mean WTD and $\mathrm{R}_{\mathrm{ECO}}$. Some missing Ts data in 2013 were calculated using a neural network (Chambers and Hastie 1992). The weights used for these networks were obtained on the basis of training with the data series from 2014. Then we analyzed the distribution of each meteorological variable (Ta, Ts and WTD). Since they did not pass the Lilliefors normality tests, adapted for large data sets $(\geq 5000$ data entries), we continued using parametric tests. To test for the differences between CTL and OTC treatments for the whole measurement period, we used the one-way ANOVA with $P \leq 0.05$ significance threshold. The impact of treatments on $\mathrm{R}_{\mathrm{ECO}}$ values was also tested using a mixed effects model to describe the repeated measures analysis. Treatment is treated as a random variable in the model. (Chambers and Hastie 1992) while Tukey's post hoc tests were used to determine the differences between treatments (Tukey HSD).

The temperature dependence of soil respiration is commonly expressed by Q10 value. Q10 values were determined for each manipulation treatment. This parameter is the rate of $\mathrm{R}_{\mathrm{ECO}}$ change determined by the interval of Ts equal $10^{\circ} \mathrm{C}$ (Winkler et al. 1996; Fang and Moncrieff 2001). Q10 values were calculated as $Q 10=(R 2 / R 1)^{10 /\left(T_{2}-T\right.} 1$, where $\mathrm{R} 2$ and $\mathrm{R} 1$ are respiration rates found at temperatures $\mathrm{T}_{2}$ and $\mathrm{T}_{1}$, respectively.

All statistical tests were performed with $\mathrm{R}$ software version 3.1.2 using the agricolae, car, doBy, lawstat, FactoMineR, fBasics, flux, nortest, xts, zoo packages (Jurasinski et al. 2014, Gastwirth et al. 2015, Gross and Liggers 2015, Mendiburu 2015, R Core Team 2014).

\section{Results}

\section{Micrometeorological Conditions in the Experimental Site}

The mean Ta of each measurements period from April to November was $13.3{ }^{\circ} \mathrm{C}$ and $14.0{ }^{\circ} \mathrm{C}$, respectively (Fig. 2b). The mean Ts in $2013\left(12.1^{\circ} \mathrm{C}\right)$ was 0.7 higher than in 2014 $\left(11.4^{\circ} \mathrm{C}\right)$ (Fig. 2a). In the first year, the mean daily Ta reached a maximum on June 20 th $\left(25.7^{\circ} \mathrm{C}\right)$ while the mean daily Ts 
Fig. 2 Daily mean values $(n=28)$ of peat temperature - Ts (a), air temperature - $\mathrm{Ta}(\mathbf{b})$ water table depth - WTD (c) in Linje mire (2013 - solid red line; 2014 dashed blue line)
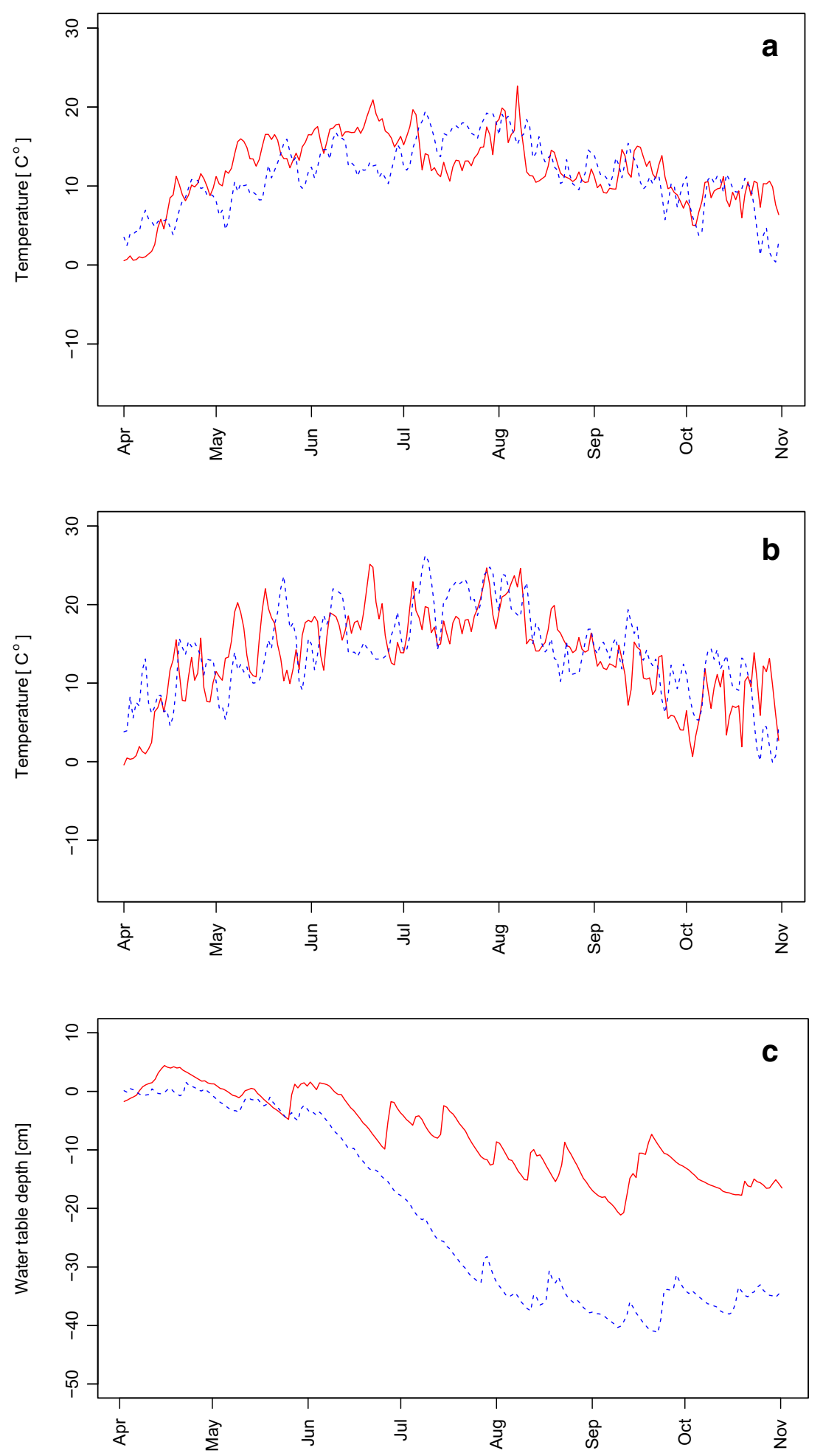

was the highest on August 7 th $\left(24.6^{\circ} \mathrm{C}\right.$ - Fig. 2b). In 2014 the highest mean daily Ta was observed on July $8\left(26.4^{\circ} \mathrm{C}\right)$ and the mean daily Ts on August 2 nd $\left(23.8^{\circ} \mathrm{C}\right)$. In 2013 the highest maximum Ta value was found on August 8th $\left(38.4{ }^{\circ} \mathrm{C}\right.$ ), while in 2014 this extreme was observed on July 28 th $\left(38.3{ }^{\circ} \mathrm{C}\right)$. With respect to the WTD (Fig. 2c), the mean value of measurement period was higher in 2013 $(-7.4 \mathrm{~cm})$ than in $2014(-21.2 \mathrm{~cm})$. The WTD during the second half of 2014 was much lower than in the corresponding period of the previous year. In the summer 2014, the WTD was more than $20 \mathrm{~cm}$ lower than in summer 2013 and this resulted in annual WTD amplitudes in $2013(18.0 \mathrm{~cm})$ lower 
than in $2014(37.4 \mathrm{~cm})$. Such fluctuations in groundwater levels may be the result of the combination of higher Ta (increasing evapotranspiration) and lower precipitation in 2014. Indeed, the annual total precipitation in $2013(477.6 \mathrm{~mm})$ was higher than in 2014 (408.7 mm).

\section{The Effect of Warming and Water Table Manipulation on Microclimate}

On average for over two years, OTCs increased Ta by $0.3{ }^{\circ} \mathrm{C}$, which is in the range of results found in other works (e.g. Buttler et al. 2015). Mean values of monthly Ta over two years were not different between OTC $\left(8.4^{\circ} \mathrm{C}\right)$ and CTL $\left(8.1^{\circ} \mathrm{C}\right)$ plots $(P=0.498)$. But mean monthly maximum Ta during this period was higher in the OTC treatments $\left(16.1^{\circ} \mathrm{C}\right)$ as compared to the CTL treatments $\left(14.9{ }^{\circ} \mathrm{C}\right)(P<0.001)$. Furthermore, mean monthly Ts over the two years were significantly lower at OTC plots than at CTL plots $(P=0.004)$. Mean values of monthly Ts were equal between the OTC $\left(7.1^{\circ} \mathrm{C}\right)$ and $\mathrm{CTL}$ $\left(7.4^{\circ} \mathrm{C}\right.$ ). If one considers only the two growing seasons, the mean of daily maximum Ta in OTC plots was increased by 1.1$1.2^{\circ} \mathrm{C}$ and $1.6-1.8^{\circ} \mathrm{C}$ during the growing seasons of 2013 and 2014 , respectively. Manipulation of the water table showed that the mean of monthly WTD for both years was statistically different between the three variants of water table treatments $(P<0.05)$, which confirms the effectiveness of the applied manipulation. Over the two years, the water level manipulation did not impact the mean of monthly $\mathrm{Ta}(P=0.689)$, but it did affect the mean of monthly Ts $(P=0.003)$.

\section{Separate Effects of Cutting, Warming and Water Table Manipulation on $\mathbf{R}_{\mathrm{ECO}}$}

The difference between daily maximum Ta in OTC and CTL plots (max delta was approx. $4{ }^{\circ} \mathrm{C}$ ) determined conspicuous differences in the observed $\mathrm{R}_{\mathrm{ECO}}$ values (Fig. 4). OTC treatments had a significant impact on Reco in $2013(P=0.006)$. Additionally, differences in water level treatments had a significant impact on mean daily $\mathrm{R}_{\mathrm{ECO}}$ values in $2013(P=$ $0.003)$ and $2014(P=0.016)$. The impact of cutting on $\mathrm{R}_{\mathrm{ECO}}$ (i.e. CTL vs CCTL) was found negligible $(P>0.05)$. In 2014, there was an interaction between OTC and cutting $(P<0.01)$. These tests showed also an interaction between OTC and WTD in $2014(\mathrm{P}=0.003)$.

\section{Overall Comparison of $\mathbf{R}_{\mathrm{ECO}}$ Between Treatments}

In 2014, there was also a significant interaction between warming, cutting and water level. The values of $\mathrm{R}_{\mathrm{ECO}}$ during the measurement period of 2013-2014 were in the range between 0 and $4.9 \mu \mathrm{mol} \mathrm{CO} \mathrm{Cm}^{-2} \mathrm{~s}^{-1}$ (Fig. 3). The mean $\mathrm{R}_{\mathrm{ECO}}$ during the growing season in $2013\left(0.58 \mu \mathrm{mol} \mathrm{CO} \mathrm{CO}_{2}\right.$ $\mathrm{m}^{-2} \mathrm{~s}^{-1}$ ) was approximately $0.2 \mu \mathrm{mol} \mathrm{CO} \mathrm{Cm}^{-2} \mathrm{~s}^{-1}$ lower than in $2014\left(0.76 \mu \mathrm{mol} \mathrm{CO} \mathrm{m}^{-2} \mathrm{~s}^{-1}\right)$.

The highest of mean daily $\mathrm{R}_{\mathrm{ECO}}$ values over the two growing seasons 2013-2014 was $0.93 \mu \mathrm{mol} \mathrm{CO}_{2} \mathrm{~m}^{-2} \mathrm{~s}^{-1}$ (DOTC), while the lowest was $0.53 \mu \mathrm{mol} \mathrm{CO} \mathrm{C}^{-2} \mathrm{~s}^{-1}$ (WCTL). If each year is considered separately, in 2013 the lowest mean daily $\mathrm{R}_{\mathrm{ECO}}$ value was observed at OTC plots $(0.51 \mu \mathrm{mol} \mathrm{CO}$ $\left.\mathrm{m}^{-2} \mathrm{~s}^{-1}\right)$, whereas in 2014 it was at COTC $(0.65 \mu \mathrm{mol} \mathrm{CO}$ $\left.\mathrm{m}^{-2} \mathrm{~s}^{-1}\right)$. In contrast, the highest values of mean daily $\mathrm{R}_{\mathrm{ECO}}$ were in both years in DOTC plots $\left(0.80 \mu \mathrm{mol} \mathrm{CO} \mathrm{C}^{-2} \mathrm{~s}^{-1}\right.$ and $1.16 \mu \mathrm{mol} \mathrm{CO} \mathrm{C}^{-2} \mathrm{~s}^{-1}$ in 2013 and 2014, respectively).

Mean values of daily $\mathrm{R}_{\mathrm{ECO}}$ in wet plots $\left(0.54 \mu \mathrm{mol} \mathrm{CO} \mathrm{CO}_{2}\right.$ $\mathrm{m}^{-2} \mathrm{~s}^{-1}$ and $0.80 \mu \mathrm{mol} \mathrm{CO} \mathrm{CO}_{2} \mathrm{~m}^{-1}$, in 2013 and 2014, respectively) were lower than $\mathrm{R}_{\mathrm{ECO}}$ values found in dry plots $\left(0.72 \mu \mathrm{mol} \mathrm{CO} \mathrm{m}^{-2} \mathrm{~s}^{-1}\right.$ and $0.91 \mu \mathrm{mol} \mathrm{CO} \mathrm{Cm}^{-2} \mathrm{~s}^{-1}$ in 2013 and 2014, respectively). Also, wet plots had the lowest mean of maximum daily $\mathrm{R}_{\mathrm{ECO}}$ values in $2013(2.92 \mu \mathrm{mol} \mathrm{CO}$ $\left.\mathrm{m}^{-2} \mathrm{~s}^{-1}\right)$, while in 2014 it was at control plots $(3.42 \mu \mathrm{mol}$ $\left.\mathrm{CO}_{2} \mathrm{~m}^{-2} \mathrm{~s}^{-1}\right)$. The dry conditions determined higher $\mathrm{CO}_{2}$ effluxes (Fig. 3).

Tukey test indicated two significantly different groups of $\mathrm{R}_{\mathrm{ECO}}$ treatments (letters A and B in Fig. 4). In both years mean $\mathrm{R}_{\mathrm{ECO}}$ values in DOTC treatment were significantly higher than the values obtained in CTL, OTC and WCTL treatments. In 2013, the CCTL belonged also to this last group, and in 2014 it was COTC.

\section{Q10 Value}

In our study Q10 coefficients varied between treatments and years, ranging from 2.0 (DOTC and COTC in 2013) to 6.1 (WOTC in 2014) (Fig. 5). The pairwise comparisons, where CTL, DCTL, CCTL and WCTL are compared with OTC, DOTC, COTC and WOTC, respectively, show that in most cases the OTC treatment increased Q10 value in 2013 and 2014 except the dry treatment in 2013 (DOTC, decrease of 0.2 ) and the wet treatment in 2013 (WOTC, decrease of 0.6). The mean Q10 value for the period of April to November 2014 was 3.3, while for the same period in 2013 it was 3.0, and for both years it was 3.1.

\section{Discussion}

\section{Additive Effect of Warming and Lowering of WTD on C Cycling}

Many studies documented that main factors impacting soil respiration $\left(\mathrm{R}_{\mathrm{ECO}}\right)$ and therefore carbon emissions are air temperature (Bubier et al. 1998; Bortoluzzi et al. 2006; Davidson 

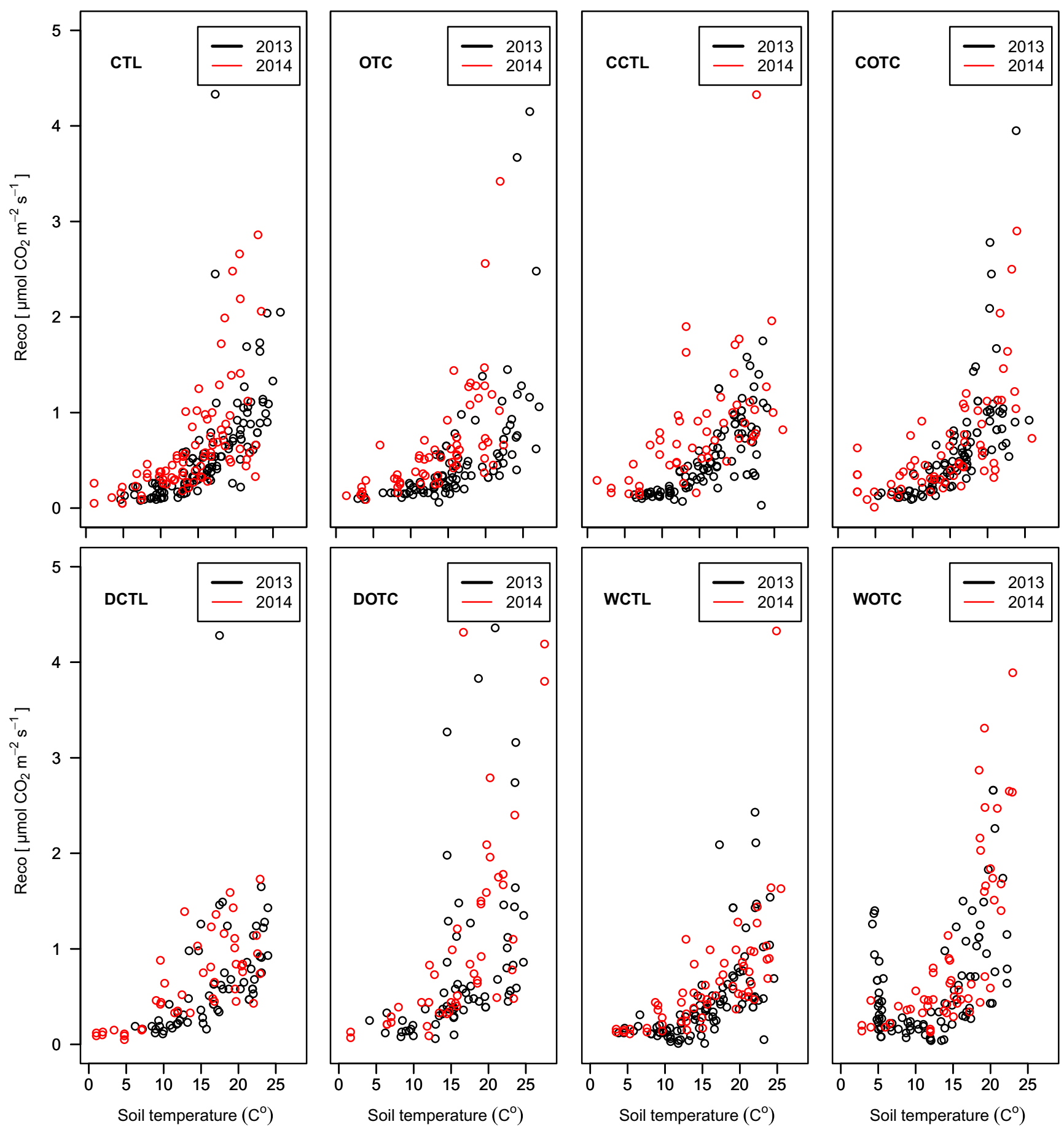

Fig. 3 The ecosystem respiration $\left(\mathrm{R}_{\mathrm{ECO}}\right)$ in relation to soil temperature (2013 black dots, 2014 - red dots)

et al. 2006; Chojnicki et al. 2010; Heijmans et al. 2013) or peat temperature (Chapman and Thurlow 1996; Silvola et al. 1996; Lafleur et al. 2005; Juszczak et al. 2013; D'Angelo et al. 2016). Approximate $1{ }^{\circ} \mathrm{C}$ temperature increase at subarctic peatlands resulted in increases of $\mathrm{R}_{\mathrm{ECO}}$ values and mobilization of carbon that was located in deeper peat layers (Dorrepaal et al. 2009). Chivers et al. (2009) stated that despite different water levels observed at their sites, there was no impact of WTD on $\mathrm{R}_{\mathrm{ECO}}$. Although, according to Lafleur et al. (2005), a variability in WTD has a major impact on the peatland respiration if the water table is close to the surface.

Our study provides experimental evidence that both warming and WTD impacted $\mathrm{R}_{\mathrm{ECO}}$, but more importantly that a combination of the increased temperature and lower WTD resulted in an additive effect on loss of carbon by respiration. The most striking differences were found at dry plots with warming (DOTC), most likely due to the enhanced aerobic conditions in the acrotelm (Chambers et al. 2011). Despite 

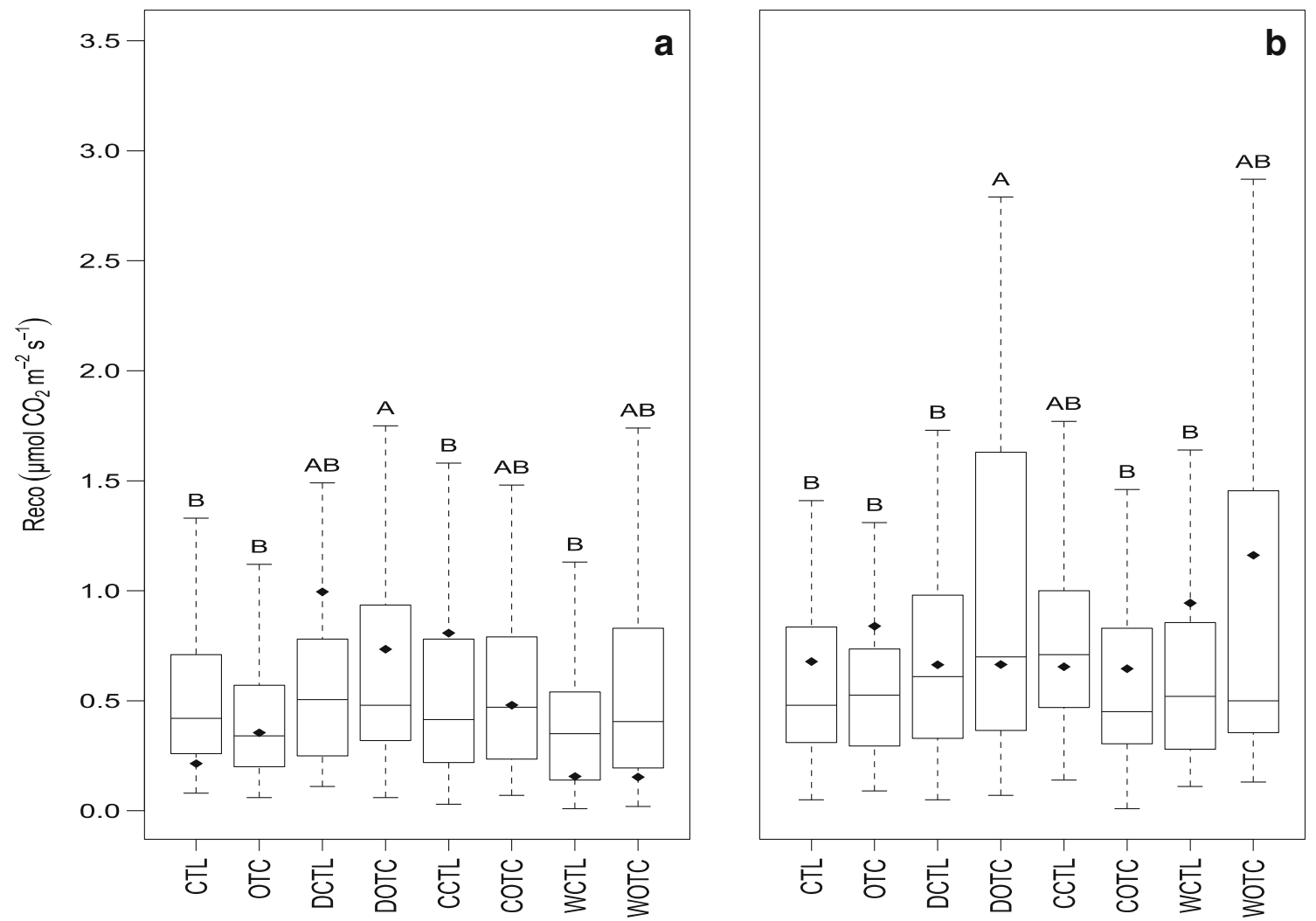

Fig. 4 Tukey test comparison for mean values of $\mathrm{R}_{\mathrm{ECO}}$ in all treatments for the growing seasons 2013 (a) and 2014 (b). The central bars indicate the median values, points indicate the mean values, the box limits indicate

inter-annual climate variability, $\mathrm{R}_{\mathrm{ECO}}$ values observed at DOTC plots were significantly different from $\mathrm{R}_{\mathrm{ECO}}$ in other treatments, in both years. This supports the statement that the impact of a single factor alone is less effective than a combined effect. Indeed, in our experiment, the warming by means of OTCs and the lowering of water table had the largest impact on soil respiration.

Our results correspond well to findings in other experimental studies. Samaritani et al. (2010) showed that the strongest differences in soil respiration were observed during the warmer and the first and third quartiles and the whiskers show the minimum and maximum values. Capital letters indicate significant differences

drier periods. Long periods without rain may result in a sharper transition between unsaturated and saturated peat layers (Hornibrook et al. 2008) and change diffusion coefficients and water saturation within the peat, which can slow down the transport of gases and solutes in the peat profile (Waddington and Roulet 1997; Fraser et al. 2001; Limpens et al. 2008). Our results show that the peatland carbon flux can be modified by even small changes in environmental conditions such as those induced by our treatments. Since processes related to carbon losses are related to temperature and hydrology, which are
Fig. 5 Mean Q10 values for each combination of treatments in 2013 (grey) and 2014 (dark grey). Error bars represent standard deviation (Control uncut plots: $N=5$, dry, cut and wet plots: $N=$ 3)

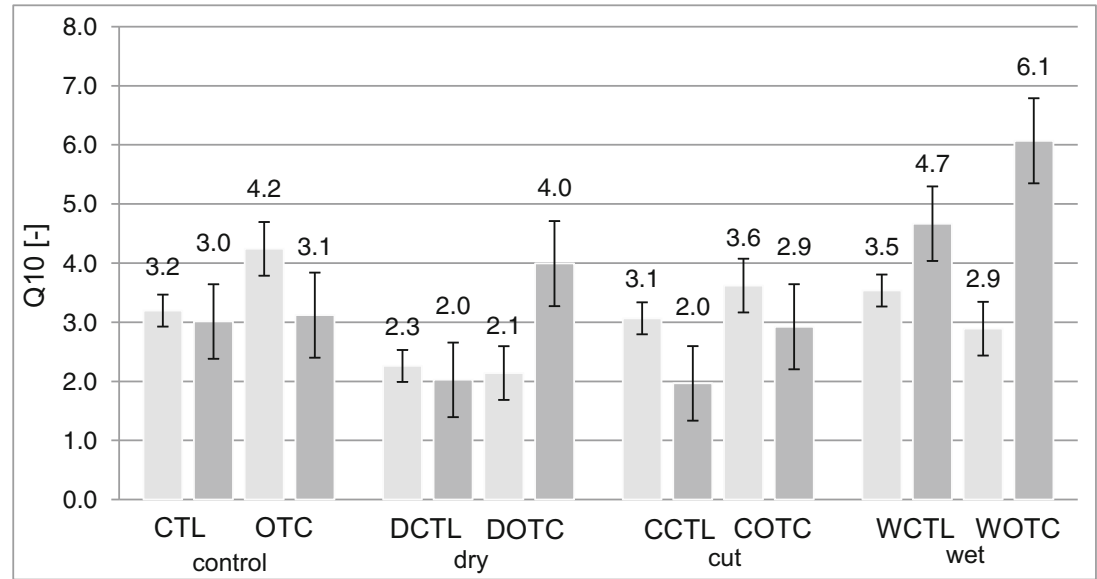


dynamically interrelated, the application of combined temperature and WTD treatments has the potential to simulate more reliably the impact of climate change on the functioning of peatland than single factor manipulative experiments.

\section{Cutting Impact on $\mathbf{R}_{\mathrm{ECO}}$}

Since the cutting may have affected the vegetation functioning and e.g. transpiration rates can be modified by this intervention, therefore we did not notice differences between control and cutting treatments in both measurement years. Also indirectly cutting decreased Q10 in 2013 (Fig. 5) by interrupted connection structures in peat monoliths, however dry and warmer year of 2014 caused increasing Q10 values (Fig. 5). So far many studies showed that clipping and removing the aboveground parts of plants decreased $\mathrm{R}_{\mathrm{ECO}}$, because this reduces soil respiration by decreasing the input of labile carbon to soil (Wan and Luo 2003; Bahn et al. 2006) and/or by weakening the assimilation supply from photosynthesis (Bahn et al. 2008). It is widely known that the cutting causes slower regeneration of plants (Silvola et al. 1996).

\section{High Yearly and Seasonal Variation of $\mathbf{R}_{\mathrm{ECO}}$}

The respiration fluxes obtained during the two-field campaigns show that higher $\mathrm{R}_{\mathrm{ECO}}$ values were recorded in 2014, which also had warmer mean annual Ta as compared to 2013. Thus, the Ts measured at 5-cm depth was probably less influential on mean annual $R_{E C O}$ values and the fact of temperature drop at OTC sites suggests that heat induced $\mathrm{CO}_{2}$ emission was mainly determined in upper layers of peat profile. Our results showed a significant difference in the Ts between CTL and OTC treatments, however mean Ts at OTC's was lower than CTL's. This result may be explained by the fact that OTCs did not affect the temperature as measured with the sensors placed $5 \mathrm{~cm}$ below the surface (Chivers et al. 2009). However, the impact of OTC may be noticeable during the freeze-thaw and extremely high temperature events (Bokhorst et al. 2013). Indeed, we have found significant effects of OTC on plots' microclimate using maximum daily Ta. Thus, the significant effect of warming on monthly $\mathrm{R}_{\mathrm{ECO}}$ values is most likely the result of the increase in the Ta inside the chamber during hot and sunny summer days (Fig. 3) (Lamentowicz et al. 2016). In these extreme conditions, the OTC can effectively change the heat balance at the peatland surface (Lamentowicz et al. 2016) - an effect which can decline rapidly with depth. The advection of relatively warm air mass during the winter time increases the speed of snow melting at the peatland surface but the OTC presence can restrict the heat transport via reduction of the wind speed over the vegetation canopy (the sensible heat flux reduction). Furthermore, the presence of snow caused thermal insulation as well as increased the albedo. Both phenomena reduced the amount of heat at the surface of the peatland. This observation corresponds well to what was described by other authors (Marion et al. 1997; Johnson et al. 2013). Seasonality in respiration rates in our study is following the monthly Ta patterns, however $\mathrm{CO}_{2}$ emission strongly depended on peat moisture. Nijp et al. (2014) presented the opinion that in many situations warming does not increase $R_{E C O}$ because of the water access limitation. Our results seem to be in contradiction to this statement since the $\mathrm{CO}_{2}$ emission in 2014 was higher $(0.2 \mu \mathrm{mol}$ $\mathrm{CO}_{2} \mathrm{~m}^{-2} \mathrm{~s}^{-1}$ ) than in 2013 with the lower water level during the second measurement season. Most probably the increase of acrotelm thickness triggered the increase of $\mathrm{CO}_{2}$ emission from the deeper peat layers.

\section{Q10 Values Describe the Dynamics of $R_{E C o}$}

The differences of peat Q10 values between treatments support previous findings that temperature and moisture have a direct influence on Sphagnum productivity (Turetsky et al. 2012) and microbial communities (Peltoniemi et al. 2015), and this is reflected in $\mathrm{R}_{\mathrm{ECO}}$. The higher temperatures elevate $\mathrm{CO}_{2}$ respiration and may also stimulate plant productivity, especially in cold regions (Rustad et al. 2001). Results of field experiments show the increased Sphagnum productivity with warming (Robroek et al. 2007), as long as there was sufficient water (Dorrepaal et al. 2003). In Linje mire, the noticeably lower Q10 values found in the dry treatment can be explained by changes in microclimate conditions that affect the microbial community (Luo et al. 2001; Allison et al. 2010; Crowther and Bradford 2013) and particularly by the lower peat moisture (Silvola et al. 1996; Suseela et al. 2012). These findings follow the results presented by other authors, Q10 parameters was also described by other authors and for wetlands have been reported as values between 2.2 and 4.2. (Lafleur et al. 2005) and from 2.0 to 8.9 (Hirota et al. 2006), 2.9-9.4 (Acosta et al. 2017). The values of this parameter in our case was ranging from 2.0 to 6.1. Q10 values depended on the depth where soil temperature was measured. High Q10 values were related with soil temperature at $10 \mathrm{~cm}$ and they considered that it reflects the influence of the low temperature range (Acosta et al. 2017). Kirschbaum (1995) suggested that high Q10 can be attributed to low soil respiration under low temperature. Here, we demonstrate that the OTC generally increased the respiration Q10 values, however in wet conditions, Q10 increased strongly with OTC (WOTC $=6.1)$, indicating a high reactivity of respiration rate when the organic matter got exposed to aerobic conditions.

\section{Estimated Yearly Carbon Loss}

The estimated values of the cumulated $\mathrm{R}_{\mathrm{ECO}}$ at Linje mire for both years $\left(113.7 \mathrm{~g} \mathrm{C}^{-} \mathrm{CO}_{2} \mathrm{~m}^{-2} \mathrm{yr}^{-1}\right)$ are smaller than at Degerö Stormyr poor fen in the middle of Sweden (404.0 g 
C-CO $\mathrm{Cm}^{-2} \mathrm{yr}^{-1}$ ) (Nillson et al. 2008; Wu et al. 2013). On the other hand, similar values of cumulated $\mathrm{R}_{\mathrm{ECO}}$ were measured at Mer Bleue raised bog (Roulet et al. 2007) and at Stordalen mixed mire (Bäckstrand et al. 2010), specifically 230.0 and $150.0 \mathrm{~g} \mathrm{C}^{-} \mathrm{CO}_{2} \mathrm{~m}^{-2} \mathrm{yr}^{-1}$, respectively. These differences may be dependent on the type of peatland (Jaatinen et al. 2007), although inter-annual variability of temperature (Pullens et al. 2016) and moisture (Turetsky et al. 2012) may strongly modify the carbon balance of the compared mire ecosystems.

\section{Conclusions}

We report on the first experimental study in a Central European peatland aiming at assessing the effect of projected climate change on $\mathrm{R}_{\mathrm{ECO}}$.

1. Our results show that OTCs changed micrometeorological conditions by the increase of Ta near the ground.

2. We show that the combined warming and lowering of water table had an additive effect on the increased peatland $\mathrm{R}_{\mathrm{ECO}}$. Respiration rates were highly seasonal and followed patterns in mean monthly temperature values.

3. Our experimental study confirms that peatland $\mathrm{R}_{\mathrm{ECO}}$ is a sensitive indicator, even of very subtle changes of micrometeorological conditions. Such sensitivity has an important implication to monitor the carbon sink function of Central European poor fens.

4. Q10 value very well describes the dynamics of $R_{\mathrm{ECO}}$ since this parameter reacted to both changes in temperature and WTD.

Acknowledgements This work was supported by Swiss Contribution to the enlarged European Union (No PSPB-013/2010) and the National Science Centre, Poland (grant No. NN306060940). We would like to thank Matthieu Mulot for his support and assistance during analysis and Anshu Rastogi for his valuable advices and remarks on the manuscript contents.

Open Access This article is distributed under the terms of the Creative Commons Attribution 4.0 International License (http:// creativecommons.org/licenses/by/4.0/), which permits unrestricted use, distribution, and reproduction in any medium, provided you give appropriate credit to the original author(s) and the source, provide a link to the Creative Commons license, and indicate if changes were made.

\section{References}

Acosta M, Juszczak R, Chojnicki B, Pavelka M, Havránková K, Lesny J, Krupková L, Urbaniak M, Machačová K, Olejnik J (2017) $\mathrm{CO}_{2}$ fluxes from different vegetation communities on a peatland ecosystem. Wetlands 37(3):423-435
Allison SD, Wallenstein MD, Bradford MA (2010) Soil-carbon response to warming dependent on microbial physiology. Nature Geoscience $3: 336-340$

Alm J, Talanov A, Saarnio S, Silvola J, Ikkonen E, Aaltonen H, Nykänen H, Martikainen PJ (1997) Reconstruction of the carbon balance for microsites in a boreal oligotrophic pine fen, finland. Oecologia 110(3):423-431. https://doi.org/10.1007/s004420050177

Alm J, Schulman L, Walden J, Nykänen H, Martikainen PJ, Silvola J (1999) Carbon balance of a boreal bog during a year with an exceptionally dry summer. Ecology 80(1):161-174.

Bäckstrand K, Crill PM, Jackowicz-Korczynski M, Mastepanov M, Christensen TR, Bastviken D (2010) Annual carbon gas budget for a subarctic peatland, Northern Sweden. Biogeosciences 7:95108. https://doi.org/10.5194/bg-7-95-2010

Bahn M, Knapp M, Garajova Z, Pfahringer N, Cernusca A (2006) Root respiration in temperate mountain grasslands differing in land use. Global Change Biology 12:995-1006. https://doi.org/10.1111/j. 1365-2486.2006.01144.x

Bahn M, Rodeghiero M, Anderson-Dunn M, Dore S, Gimeno C, Drösler M, Williams M, Ammann C, Berninger F, Flechard C, Jones S (2008) Soil respiration in European grasslands in relation to climate and assimilate supply. Ecosystems 11:1352-1367. https://doi.org/ 10.1007/s10021-008-9198-0

Bokhorst S, Huiskes A, Aerts R, Convey P, Cooper EJ, Dalen L, Erschbamer B, Gudmundsson J, Hofgaard A, Hollister RD, Johnstone J, Jónsdóttir IS, Lebouvier M, Van de Vijver B, Wahren $\mathrm{CH}$, Dorrepaal E (2013) Variable temperature effects of open top chambers at polar and alpine sites explained by irradiance and snow depth. Global Change Biology 19(1):64-74. https://doi.org/10.1111/ gcb. 12028

Boński M, Bońska U (2004) Plan ochrony Rezerwatu Przyrody "Linje". (Conservation Plan for Linje Nature Reserve). Developed at the request of the Kujawsko-Pomeranian Governor, Torun, 57 pp. plus illustrations (in Polish). http://nocek.rdos-bydgoszcz.pl/download/ natura2k/dokumentacja/Dok_PO_RP/Linje/PO_Linje.pdf. Accessed 22 Sep 2016

Bortoluzzi E, Epron D, Siegenthaler A, Gilbert D, Buttler A (2006) Carbon balance of a European mountain bog at contrasting stages of regeneration. The New Phytologist 172(4):708-718. https://doi. org/10.1111/j.1469-8137.2006.01859.x

Bragazza L (2008) A climatic threshold triggers the die-off of peat mosses during an extreme heat wave. Global Change Biology 14(11):26882695

Bragazza L, Buttler A, Robroek BJM, Albrecht R, Zaccone C, Jassey VEJ, Signarbieux C (2016) Persistent high temperature and low precipitation reduce peat carbon accumulation. Global Change Biology 22(12):4114-4123. https://doi.org/10.1111/gcb.13319

Bubier JL, Crill PM, Moore TR, Savage K, Varner RK (1998) Seasonal patterns and controls on net ecosystem $\mathrm{CO}_{2}$ exchange in a boreal peatland complex. Global Biogeochemical Cycles 12:703

Buttler A, Robroek BJM, Laggoun-Défarge F, Jassey VEJ, Pochelon C, Bernard G, Delarue F, Gogo S, Mariotte P, Mitchell EAD, Bragazza L (2015) Experimental warming interacts with soil moisture to discriminate plant responses in an ombrotrophic peatland. Journal of Vegetation Science 26(5):964-974. https://doi.org/10.1111/jvs.12296

Chambers JM, Hastie TJ (1992) Statistical models in S. Chapman and Hall. New York, pp 421-427

Chambers FM, Beilman DW, Yu Z (2011) Methods for determining peat humification and for quantifying peat bulk density, organic matter and carbon content for palaeostudies of climate and peatland carbon dynamics. Mires and Peat 7:1-10

Chapman SJ, Thurlow M (1996) The influence of climate on $\mathrm{CO}_{2}$ and $\mathrm{CH} 4$ emissions from organic soils. Agricultural Forest Meteorology 79:205-217

Chivers MR, Turetsky MR, Waddington JM, Harden JW, McGuire AD (2009) Effects of experimental water table and temperature 
manipulations on ecosystem $\mathrm{CO}_{2}$ fluxes in an Alaskan rich fen. Ecosystems 12(8):1329-1342. https://doi.org/10.1007/s10021-0099292-y

Chojnicki BH, Michalak M, Acosta M, Juszczak R, Augustin J, Drösler M, Olejnik J (2010) Measurements of carbon dioxide fluxes by chamber method at the Rzecin wetland ecosystem, Poland - tags: CARBON dioxide WETLAND ecology. Polish Journal of Environmental Studies 19(2):283-291

Christensen JH, Hewitson B, Busuioc A, Chen A, Gao X, Held R, Jones R, Kolli RK, Kwon WK, Laprise R, Magaña Rueda V, Mearns L, Menéndez CG, Räisänen J, Rinke A, Sarr A, Whetton P, Arrit R, Benestad R, Beniston M, Bromwich D, Caya D, Comiso J, de Elia R, Dethloff K (2007) Near-term climate change: projections and predictability. In: Climate change 2007: the physical science basis. Contribution of Working Group I to the Fourth Assessment Report of the Intergovernmental Panel on Climate Change. University Press, Cambridge, pp 847-940

Clymo RS, Turunen J, Tolonen K (1998) Carbon accumulation in peatland. Oikos 81(2):368-388. https://doi.org/10.2307/3547057

Crowther TW, Bradford MA (2013) Thermal acclimation in widespread heterotrophic soil microbes. Ecology Letters 16:469-477

D’Angelo BD, Gogo S, Laggoun-défarge F (2016) Agricultural and Forest meteorology soil temperature synchronisation improves representation of diel variability of ecosystem respiration in Sphagnum peatlands. Agricultural and Forest Meteorology 223:95-102. https:// doi.org/10.1016/j.agrformet.2016.03.021

Davidson EA, Janssens IA, Luo Y (2006) On the variability of respiration in terrestrial ecosystems: moving beyond Q10. Global Change Biology 12:154

Dieleman CM, Branfireun BA, McLaughlin JW, Lindo Z (2015) Enhanced carbon release under future climate conditions in a peatland mesocosm experiment: the role of phenolic compounds. Plant and Soil 400:81-91

Dorrepaal E, Aerts R, Cornelissen JH, Callaghan TV, Van Logtestijn RS (2003) Summer warming and increased winter snow cover affect Sphagnum fuscum growth, structure and production in a sub-arctic bog. Global Change Biology 10:93-104

Dorrepaal E, Toet S, Van logtestijn RSP, Swart E, Van De Weg MJ, Callaghan TV, Aerts R (2009) Carbon respiration from subsurface peat accelerated by climate warming in the subarctic. Nature 460 : 616-619

Fang C, Moncrieff JB (2001) The dependence of soil CO 2 efflux on temperature. Soil Biology and Biochemistry 33(2):155-165

Fekete BM, Wisser D, Kroeze C, Mayorga E, Bouwman L, Wollheim WM, Vörösmarty C (2010) Millennium ecosys- tem assessment scenario drivers (1970-2050): climate and hydrological alterations. Global Biogeochemical Cycles 24:GB0A12. https://doi.org/10. 1029/2009GB003593

Fraser CJD, Roulet NT, Moore TR (2001) Hydrology and dissolved organic carbon biogeochemistry in an ombrotrophic bog. Hydrological Processes 15(16):3151-3166

Frolking S, Talbot J, Jones MC, Treat CC, Kauffman JB, Tuittila ES, Roulet N (2011) Peatlands in the Earth's 21st century climate system. Environmental Reviews 19:371-396. https://oi.org/10.1139/a11-014

Gastwirth JL, Gel YR, Hui WWL, Lyubchich V, Miao W, Noguchi K (2015) Lawstat: tools for biostatistics, public policy, and law with R. In. R package, version 2.5. Available via https://cran.r-project.org/ web/packages/lawstat/. Accessed 03 Mar 2015

Giardina CP, Ryan MG (2000) Evidence that decomposition rates of organic carbon in mineral soil do not vary with temperature. Nature 404(6780):858-861

Gorham E (1991) Northern peatlands: role in the carbon cycle and probably responses to climate warming. Ecological Applications. https:// doi.org/10.2307/1941811
Gross J, Liggers U (2015) Nortest: tests for normality, version 1.0-4. Available via https://cran.r-project.org/web/packages/nortest/. Accessed 10 Mar 2015

Gunnarsson U (2005) Global patterns of sphagnum productivity. Journal of Bryology 27:269-279

Hałas S, Słowiński M, Lamentowicz M (2008) Relacje między czynnikami meteorologicznymi i hydrologią małego torfowiska mszarnego na Pomorzu. Stud Limnolog Telmatolog 2(1):15-26

Heijmans M, van der Knaap YAM, Holmgren M, Limpens J (2013) Persistent versus transient tree encroachment of temperate peat bogs: effects of climate warming and drought events. Global Change Biology 19:2240-2250. https://doi.org/10.1111/gcb.12202

Hirota M, Tang Y, Hu Q, Hirata S, Kato T, Mo W, Mariko S (2006) Carbon dioxide dynamics and controls in a deep-water wetland on the Qinghai-Tibetan Plateau. Ecosystems 9(4):673-688

Hornibrook ERC, Bowes HL, Culbert A, Gallego-Sala AV (2008) Methanotrophy potential versus methane supply by pore water diffusion in peatlands. Biogeosciences Discussions 5(3):2607-2643. https://doi.org/10.5194/bg-6-1491-2009

IPCC Working Group 1, Stocker TF, Qin D, Plattner GK, Tignor M, Allen SK, ..., Midgley PM (2013) IPCC, 2013: Climate change 2013: the physical science basis. contribution of working group $i$ to the fifth assessment report of the intergovernmental panel on climate change. IPCC AR5:1535

Jaatinen K, Fritze H, Laine J, Laiho R (2007) Effects of short-and longterm water-level drawdown on the populations and activity of aerobic decomposers in a boreal peatland. Global Change Biology 13: $491-510$

Johnson CP, Pypker TG, Hribljan J, Chimner R (2013) Open top chambers and infrared lamps: a comparison of heating efficacy and $\mathrm{CO}_{2} /$ CH4 dynamics in a Northern Michigan peatland. Ecosystems 16(5): 736-748. https://doi.org/10.1007/s10021-013-9646-3

Jurasinski G, Koebsch F, Guenther A, Beetz S (2014) Flux rate calculation from dynamic closed chamber measurements, version 0.3-0. Available via https://cran.r-project.org/web/packages/flux/. Accessed 03 May 2016

Juszczak R, Humphreys E, Acosta M, Michalak-Galczewska M, Kayzer D, Olejnik J (2013) Ecosystem respiration in a heterogeneous temperate peatland and its sensitivity to peat temperature and water table depth. Plant and Soil 366(1-2):505-520. https://doi.org/10.1007/ s11104-012-1441-y

Kirkinen J, Minkkinen K, Penttilä T, Kojola S, Sievänen R, Alm J, Saarnio S, Silvan N, Laine J, Savolainen I (2007) Greenhouse impact due to different peat fuel utilization chains in Finland - a lifecycle approach. Boreal Environment Research 12:211-223

Kirkinen J, Soimakallio S, Mäkinen T, Savolainen I (2010) Greenhouse impact assessment of peat-based Fischer-Tropsch diesel life cycle. Energy Policy 38(1):301-311. https://doi.org/10.1016/j.enpol.2009. 09.019

Kirschbaum MU (1995) The temperature dependence of soil organic matter decomposition, and the effect of global warming on soil organic C storage. Soil Biology and Biochemistry 27(6):753-760

Kloss M (2005) Palaeobotanical studies of raised mires. Monographiae Botanicae 94:5-18

Kloss M, Żurek S (2005) Geology of raised mire deposits. Monographiae Botanicae 94:67-80

Komulainen VM, Tuittila ES, Vasander H, Laine J (1999) Restoration of drained peatlands in southern Finland: initial effects on vegetation change and $\mathrm{CO}_{2}$ balance. Journal of Applied Ecology 36:634-648

Kottek M, Grieser J, Beck C, Rudolf B, Rubel F (2006) World map of the Köppen-Geiger climate classification updated. Meteorologische Zeitschrift 15(3):259-263. https://doi.org/10.1127/0941-2948/ 2006/0130

Kucharski L, Kloss M (2005) Contemporary vegetation of selected raised mires and its preservation. Monographiae Botanicae 94:37-64 
Lafleur PM, Moore TR, Roulet NT, Frolking S (2005) Ecosystem respiration in a cool temperate bog depends on peat temperature but not water table. Ecosystems 8(6):619-629. https://doi.org/10.1007/ s10021-003-0131-2

Lamentowicz M, Słowińska S, Słowiński M, Jassey VEJ, Chojnicki BH, Reczuga MK, Zielińska M, Marcisz K, Lamentowicz Ł, Barabach J, Samson M, Kołaczek P, Buttler A (2016) Combining short-term manipulative experiments with long-term palaeoecological investigations at high resolution to assess the response of Sphagnum peatlands to drought, fire and warming. Mires and Peat 18(20):117. https://doi.org/10.19189/MaP.2016.OMB.244

Lappalainen E (1996) General review on world peatland and peat resources. In: Lappalainen E (ed) Global Peat Resources. International Peat Society and Geological Survey of Finland, Jyska, pp 53-56

Limpens J, Berendse F, Blodau C, Canadell JG, Freeman C, Holden J, Roulet N, Rydin H, Schaepman-Strub G (2008) Peatlands and the carbon cycle: from local processes to global implications - a synthesis. Biogeosciences 5:1475-1491. https://doi.org/10.5194/bgd-5$1379-2008$

Lorenc H (2005) Atlas klimatu Polski. Instytut Meteorologii i Gospodarki Wodnej, Warszawa

Lund M, Lafleur PM, Roulet NT, Lindroth A, Christensen TR, Aurela M, Chojnicki BH, Flanagan LB, Humphreys ER, Laurila T, Oechel WC, Olejnik J, Rinne J, Schubert P, Nilsson MB (2010) Variability in exchange of $\mathrm{CO}_{2}$ across 12 northern peatland and tundra sites. Global Change Biology 16(9):2436-2448. https://doi. org/10.1111/j.1365-2486.2009.02104.x

Lund M, Christensen TR, Lindroth A, Schubert P (2012) Effects of drought conditions on the carbon dioxide dynamics in a temperate peatland. Environmental Research Letters 7(4):1-7. https://doi.org/ 10.1088/1748-9326/7/4/045704

Luo Y, Wan S, Hui D, Wallace L (2001) Acclimation of soil respiration to warming in a tall grass prairie. Nature 613:622-625

Marion GM, Henry GHR, Freckman DW, Johnstone J, Jones G, Jones MH, Levesque E, Molau U, Mølgaard P, Parsons AN, Virginia RA (1997) Open-top designs for manipulating field temperature in highlatitude ecosystems. Global Change Biology 3:20-32. https://doi. org/10.1111/j.1365-2486.1997.gcb136.x

Mendiburu F (2015) Agricolae. Statistical procedures for agricultural research with R. In. R package, version 1.2-3. Available via https://cran.r-project.org/web/packages/agricolae/. Accessed 15 Mar 2015

Nijp JJ, Limpens J, Metselaar K, van der Zee SEATM, Berendse F, Robroek BJM (2014) Can frequent precipitation moderate the impact of drought on peatmoss carbon uptake in northern peatlands? The New Phytologist 203:70-80. https://doi.org/10.1111/nph.12792

Nillson M, Sagerfors J, Buffam I, Laudon H, Eriksson T, Grelle A, Klemedtsson L, Weslein P, Lindroth A (2008) Contemporary carbon accumulation in a boreal oligotrophic minerogenic mire - a significant sink after accounting for all C-fluxes. Global Change Biology 14:2317-2332. https://doi.org/10.1111/j.1365-2486.2008.01654.x

Northon K (2017) Title of subordinate document. In: NASA, NOAA Data Show 2016. Warmest year on record globally. Available via DIALOG. https://www.nasa.gov/press-release/nasa-noaa-data-show2016-warmest-year-on-record-globally. Accessed 26 Jan 2017

Peltoniemi K, Laiho R, Juottonen H, Kiikkilä O, Mäkiranta P, Minkkinen K, Pennanen T, Penttilä T, Sarjala T, Tuittila ES, Tuomivirta T (2015) Microbial ecology in a future climate: effects of temperature and moisture on microbial communities of two boreal fens. FEMS Microbiology Ecology 91(7). https://doi.org/10.1093/femsec/fiv062

Pullens JWM, Sottocornola M, Kiely G, Toscano P, Gianelle D (2016) Carbon fluxes of an alpine peatland in Northern Italy. Agricultural and Forest Meteorology 220:69-82. https://doi.org/10.1016/j. agrformet.2016.01.012
R Core Team (2014) R: A language and environment for statistical computing. R Foundation for Statistical Computing, Vienna, Austria. http://www.R-project.org/. Accessed 25 Mar 2015

Robroek BJ, Limpens J, Breeuwer A, Schouten MGC (2007) Effects of water level and temperature on performance of four Sphagnum mosses. Plant Ecology 190:97-107. https://doi.org/10.1007/ s11258-006-9193-5

Robroek BJ, Jassey VE, Kox MA, Berendsen RL, Mills RT, Cecillon L, Puissant J, Meima-Franke M, Bakker PA, Bodelier PL (2015) Peatland vascular plant functional types affect methane dynamics by altering microbial community structure. Journal of Ecology 103(4):925-934. https://doi.org/10.1111/1365-2745.12413

Roulet NT, Lafleur PM, Richard PJH, Moore TR, Humphreys ER, Bubier JL (2007) Contemporary carbon balance and late Holocene carbon accumulation in a northern peatland. Global Change Biology 13: 397-411. https://doi.org/10.1111/j.1365-2486.2006.01292.x

Rustad LE, Campbell JL, Marion GM, Norby RJ, Mitchell MJ, Hartley AE, Cornelissen JHC, Gurevitch J, Gcte N (2001) A meta-analysis of the response of soil respiration, net nitrogen mineralization, and aboveground plant growth to experimental ecosystem warming. Oecologia 126(4):543-562

Rydin H, Jeglum JK (2013) The biology of peatlands, 2e. Oxford University Press, Oxford, Austral Ecology 40(8):18-19. https:// doi.org/10.1111/aec.12290

Samaritani E, Siegenthaler A, Yli-Petäys M, Buttler A, Christin PA, Mitchell EAD (2010) Seasonal net ecosystem carbon exchange of a regenerating cutaway bog: how long does it take to restore the Csequestration function? Restoration Ecology 19(4):480-489. https:// doi.org/10.1111/j.1526-100X.2010.00662.x

Shaver GR, Canadell J, Chapin FS, Gurevitch J, Harte J, Henry G, Ineson P, Jonasson S, Melillo J, Louis Pitelka L, Rustad L (2000) Global warming and terrestrial ecosystems: a conceptual framework for analysis. Bioscience 50(10):871-882.

Silvola J, Alm J, Ahlholm U, Nykänen H, Martikainen PJ (1996) CO2 fluxes from peat in boreal mires under varying temperature and moisture conditions. Journal of Ecology 84(2):219-228. https:// doi.org/10.2307/2261357

Smith LC, Sheng Y, MacDonald GM (2007) A first pan-Arctic assessment of the influence of glaciation, permafrost, topography and peatlands on northern hemisphere lake distribution. Permafrost and Periglacial Processes 18(2):201-208

Strack M, Waddington JM (2007) Response of peatland carbon dioxide and methane fluxes to a water table drawdown experiment. Global Biogeochemical Cycles 21:GB1007

Suseela V, Conant RT, Wllenstein MD, Dukes JS (2012) Effects of soil moisture on the temperature sensitivity of heterotrophic respiration vary seasonally in an old-field climate change experiment. Global Change Biology 18:336-348

Turetsky M, Wieder RK, Halsey L, Vitt D (2002) Current disturbance and the diminishing peatland carbon sink. Geophysical Research Letters 29

Turetsky MR, Crow SE, Evans RJ, Vitt DH, Wieder RK (2008) Tradeoffs in resource allocation among moss species control decomposition in boreal peatlands. Journal of Ecology 96:1297-1305

Turetsky MR, Bond-Lamberty B, Euskirchen E, Talbot J, Frolking S, McGuire AD, Tuittila ES (2012) The resilience and functional role of moss in boreal and arctic ecosystems. The New Phytologist 196:49-67

Turunen J, Tomppo E, Tolonen K, Reinikainen A (2002) Estimating carbon accumulation rates of undrained mires in Finland - application to boreal and subarctic regions. The Holocene 12(1):69-80. https://doi.org/10.1191/0959683602hl522rp

Valentini R, Matteucci G, Dolman AJ, Schulze ED, Rebmann C, Moors EJ, Granier A, Gross P, Jensen NO, Pilegaard K, Lindroth A, Grelle A, Bernhofer C, Grünwald T, Aubinet M, Ceulemans R, Kowalski AS, Vesala T, Rannik U, Berbigier P, Loustau D, Gudmundsson J, Thorgeirsson H, Ibrom A, Morgenstern K, Clement R (2000) Respiration as the main determinant of carbon balance in 
European forests. Nature 404(6780):861-865. https://doi.org/10. 1038/35009084

Waddington JM, Roulet NT (1997) Groundwater flow and dissolved carbon movement in a boreal peatland. Journal of Hydrology 191(1):122-138

Waddington JM, Morris PJ, Kettridge N, Granath G, Thompson DK, Moore PA (2015) Hydrological feedbacks in northern peatlands. Ecohydrology 8:113-127

Wan S, Luo Y (2003) Substrate regulation of soil respiration in a tallgrass prairie: results of a clipping and shading experiment. Global Biogeochemical Cycles 17:1-12. https://doi.org/10.1029/ 2002GB001971

Ward SE, Orwin KH, Ostle NJ, Briones MJI, Thomson BC, Griffiths RI, Oakley S, Quirk H, Bardgett RD (2015) Vegetation exerts a greater control on litter decomposition than climate warming in peatlands. Ecology 96:113-123
Weltzin JF, Bridgham SD, Pastor J, Chen JQ, Harth C (2003) Potential effects of warming and drying on peatland plant community composition. Global Change Biology 9:141-151

Winkler JP, Cherry RS, Schlesinger WH (1996) The Q 10 relationship of microbial respiration in a temperate forest soil. Soil Biology and Biochemistry 28(8):1067-1072

Wu J, Roulet NT, Sagerfors J, Nilsson M (2013) Simulation of six years of carbon fluxes for a sedge-dominated oligotrophic minerogenic peatland in northern Sweden using the McGill wetland model (MWM). Journal of Geophysical Research: Biogeosciences 118: 795-807. https://doi.org/10.1002/jgrg.20045

Yu Z, Loisel J, Brosseau DP, Beilman DW, Hunt SJ (2010) Global peatland dynamics since the last glacial maximum. Geophysical Research Letters 37(13):1-5. https://doi.org/10.1029/ 2010GL043584 